Supplement of

\title{
Estimating the thickness of unconsolidated coastal aquifers along the global coastline
}

D. Zamrsky et al.

Correspondence to: Daniel Zamrsky (d.zamrsky@uu.nl)

The copyright of individual parts of the supplement might differ from the CC BY 4.0 License. 
Table S1. Borehole validation dataset sources

\begin{tabular}{|l|l|}
\hline Dataset Name & Source \\
\hline CPRM & $\begin{array}{l}\text { Geological survey of Brazil, c2016, published by Companhia de Pesquisa de } \\
\text { Recursos Minerais [Accessed 2016, August], http://www.cprm.gov.br/ }\end{array}$ \\
\hline GeoVIC & $\begin{array}{l}\text { Online geology portal of Victoria, Australia, c2016, published by the state of } \\
\text { Victoria } \\
\text { info.dpi.vic.gov.au/sd_weave/anonymous.html }\end{array}$ \\
\hline CGS & $\begin{array}{l}\text { China Geological Survey, 2012. Groundwater serial maps of Asia: Hydrogeological } \\
\text { map, Groundwater resources map, Geothermal map, Sinomaps Press. }\end{array}$ \\
\hline
\end{tabular}

Table S2. Literature validation dataset sources

\begin{tabular}{|l|l|}
\hline Polygon ID & Source \\
\hline $\mathbf{1}$ & $\begin{array}{l}\text { Lagudu, S. et al., 2013. Use of Geophysical and Hydrochemical Tools to Investigate } \\
\text { Seawater Intrusion in Coastal Alluvial Aquifer, Andhra Pradesh, India. In C. } \\
\text { Wetzelhuetter, ed. Groundwater in the Coastal Zones of Asia-Pacific. Dordrecht: } \\
\text { Springer Netherlands, pp. 49-65. }\end{array}$ \\
\hline $\mathbf{2}$ & $\begin{array}{l}\text { Singh, S.C., 2013. Geophysical Viewpoints for Groundwater Resource Development } \\
\text { and Management in Coastal Tracts. In C. Wetzelhuetter, ed. Groundwater in the } \\
\text { Coastal Zones of Asia-Pacific. Dordrecht: Springer Netherlands, pp. 67-87. }\end{array}$ \\
$\begin{array}{l}\text { Duerrast, H. \& Srattakal, J., 2013. Geophysical Investigations of Saltwater Intrusion } \\
\text { into the Coastal Groundwater Aquifers of Songkhla City, Southern Thailand. In C. } \\
\text { Wetzelhuetter, ed. Groundwater in the Coastal Zones of Asia-Pacific. Dordrecht: } \\
\text { Springer Netherlands, pp. 155-175. }\end{array}$ \\
\hline $\mathbf{4}$ & $\begin{array}{l}\text { Sherif, M., Almulla, M. \& Shetty, A., 2013. Seawater Intrusion Assessment and } \\
\text { Mitigation in the Coastal Aquifer of Wadi Ham. In C. Wetzelhuetter, ed. Groundwater } \\
\text { in the Coastal Zones of Asia-Pacific. Dordrecht: Springer Netherlands, pp. 271-294. }\end{array}$ \\
$\begin{array}{l}\text { Leonhard, L., Burton, K. \& Milligan, N., 2013. Gascoyne River, Western Australia; } \\
\text { Alluvial Aquifer, Groundwater Management and Tools. In C. Wetzelhuetter, ed. } \\
\text { Groundwater in the Coastal Zones of Asia-Pacific. Dordrecht: Springer Netherlands, } \\
\text { pp. 359-378. }\end{array}$ \\
\hline $\begin{array}{l}\text { Wagner, F., Tran, V.B. \& Renaud, F.G., 2012. Groundwater Resources in the Mekong } \\
\text { Delta: Availability, Utilization and Risks. In F. G. Renaud \& C. Kuenzer, eds. The } \\
\text { Mekong Delta System: Interdisciplinary Analyses of a River Delta. Dordrecht: } \\
\text { Springer Netherlands, pp. 201-220. } \\
\text { Benkabbour, B., Toto, E.A. \& Fakir, Y., 2004. Using DC resistivity method to } \\
\text { characterize the geometry and the salinity of the Plioquaternary consolidated coastal }\end{array}$ \\
\hline $\mathbf{7}$ &
\end{tabular}




\begin{tabular}{|c|c|}
\hline & $\begin{array}{l}\text { aquifer of the Mamora plain, Morocco. Environmental Geology, 45(4), pp.518-526. } \\
\text { Available at: http://link.springer.com/10.1007/s00254-003-0906-y. } \\
\text { Amharref, M. et al., 2007. Cartographie de la vulnérabilité à la pollution des eaux } \\
\text { souterraines: Application à la plaine du Gharb ( Maroc ). Journal of Water Science, } \\
\text { 20(2), pp.185-199. }\end{array}$ \\
\hline 8 & $\begin{array}{l}\text { Chen, J. et al., 2014. Clay minerals in the Pliocene - Quaternary sediments of the } \\
\text { southern Yangtze coast, China: Sediment sources and palaeoclimate implications. } \\
\text { Journal of Palaeogeography, 3(3), pp.297-308. Available at: } \\
\text { http://dx.doi.org/10.3724/SP.J.1261.2014.00057. }\end{array}$ \\
\hline 9 & $\begin{array}{l}\text { Cobaner, M. et al., 2012. Three-dimensional simulation of seawater intrusion in coastal } \\
\text { aquifers: A case study in the Goksu Deltaic Plain. Journal of Hydrology, 464-465, } \\
\text { pp.262-280. Available at: http://dx.doi.org/10.1016/j.jhydrol.2012.07.022. }\end{array}$ \\
\hline 10 & $\begin{array}{l}\text { Carretero, S. et al., 2013. Impact of sea-level rise on saltwater intrusion length into the } \\
\text { coastal aquifer, Partido de La Costa, Argentina. Continental Shelf Research, 61-62, } \\
\text { pp.62-70. Available at: http://dx.doi.org/10.1016/j.csr.2013.04.029. }\end{array}$ \\
\hline 11 & $\begin{array}{l}\text { Rasmussen, P. et al., 2013. Assessing impacts of climate change, sea level rise, and } \\
\text { drainage canals on saltwater intrusion to coastal aquifer. Hydrology and Earth System } \\
\text { Sciences, 17(1), pp.421-443. Available at: http://www.hydrol-earth-syst- } \\
\text { sci.net/17/421/2013/. }\end{array}$ \\
\hline 12 & $\begin{array}{l}\text { Kalm, V. \& Gorlach, A., 2014. Impact of bedrock surface topography on spatial } \\
\text { distribution of Quaternary sediments and on the flow pattern of late Weichselian } \\
\text { glaciers on the East European Craton (Russian Plain). Geomorphology, 207, pp.1-9. } \\
\text { Available at: http://dx.doi.org/10.1016/j.geomorph.2013.10.022. }\end{array}$ \\
\hline 13 & $\begin{array}{l}\text { Chen, J. et al., 2014. Clay minerals in the Pliocene - Quaternary sediments of the } \\
\text { southern Yangtze coast, China: Sediment sources and palaeoclimate implications. } \\
\text { Journal of Palaeogeography, 3(3), pp.297-308. Available at: } \\
\text { http://dx.doi.org/10.3724/SP.J.1261.2014.00057. }\end{array}$ \\
\hline 14 & $\begin{array}{l}\text { Sefelnasr, A. \& Sherif, M., 2014. Impacts of Seawater Rise on Seawater Intrusion in } \\
\text { the Nile Delta Aquifer, Egypt., 52(2), pp.264-276. }\end{array}$ \\
\hline 15 & $\begin{array}{l}\text { Singaraja, C. et al., 2015. A study on the status of saltwater intrusion in the coastal hard } \\
\text { rock aquifer of South India. Environment, Development and Sustainability, 17(3), } \\
\text { pp.443-475. Available at: http://dx.doi.org/10.1007/s10668-014-9554-5. }\end{array}$ \\
\hline 16 & $\begin{array}{l}\text { Khaki, M. et al., 2016. Integrated geoelectrical and hydrogeochemical investigation for } \\
\text { mapping the aquifer at Langat Basin, Malaysia. Environmental Earth Sciences, 75(4), } \\
\text { pp.1-14. Available at: "http://dx.doi.org/10.1007/s12665-015-5182-0. }\end{array}$ \\
\hline 17 & $\begin{array}{l}\text { Giresse, P. et al., 2000. Successions of sea-level changes during the Pleistocene in } \\
\text { Mauritania and Senegal distinguished by sedimentary facies study and U / Th dating., } \\
170 . \\
\text { Sylla, M., Medou, J.O. \& Samb, E.., 1997. Contribution of the instaneous well logging } \\
\text { to the study of the indurations. Bulletin of the International Association of Engineering } \\
\text { Geology, (55). }\end{array}$ \\
\hline 18 & $\begin{array}{l}\text { Nicholas, C.J. et al., 2006. Stratigraphy and sedimentology of the Upper Cretaceous to } \\
\text { Paleogene Kilwa Group, southern coastal Tanzania. , 45, pp.431-466. }\end{array}$ \\
\hline 19 & $\begin{array}{l}\text { Y. Yechieli, O. Sivan (2010), Using geochemical tools to study the distribution of } \\
\text { saline groundwater in aquifers separated by aquitards: examples from Israel, paper } \\
\text { presented at the } 21 \text { th Salt Water Intrusion Meeting, Azores, Portugal }\end{array}$ \\
\hline 20 & $\begin{array}{l}\text { Dirks et al. (1988), Groundwater in Bekasi district, West Java, Indonesia, paper } \\
\text { presented at the 10th Salt Water Intrusion Meeting, Gent, Belgium }\end{array}$ \\
\hline 21 & $\begin{array}{l}\text { McPherson, A. \& Jones, A., 2005. Appendix D: Perth Basin geology review and site } \\
\text { class assessment. Natural Hazard Risk in Perth, pp.313-344. Available at: } \\
\text { https://www.icsm.gov.au/image_cache/GA6548.pdf. }\end{array}$ \\
\hline 22 & $\begin{array}{l}\text { Ransley, T.R., Radke, B.M., Feitz, A.J., Kellett, J.R., Owens, R., Bell, J., Stewart, G. } \\
\text { and Carey, H. 2015. Hydrogeological Atlas of the Great Artesian Basin, Geoscience } \\
\text { Australia, Canberra. }\end{array}$ \\
\hline
\end{tabular}




\begin{tabular}{|c|c|}
\hline & http://dx.doi.org/10.11636/9781925124668 \\
\hline 23 & $\begin{array}{l}\text { Yeates, A.N. et al., 1984. Regional geology of the onshore Canning Basin, Western } \\
\text { Australia. The Canning Basin, Western Australia, pp.23-56. }\end{array}$ \\
\hline 24 & $\begin{array}{l}\text { E. Custodio (1992), Preliminary outlook of saltwater intrusion conditions in the } \\
\text { Donana National Park (southern Spain), paper presented at 12th Salt Water Intrusion } \\
\text { Meeting, Barcelona, Spain } \\
\text { J.L. Plata and F.M. Rubio (2004), Study of the salt water - fresh water interface in } \\
\text { environments of low resistivity: Donana aquifer (Spain), paper presented at the 18th } \\
\text { Salt Water Intrusion Meeting, Cartagena, Spain }\end{array}$ \\
\hline 25 & $\begin{array}{l}\text { Custodio, E., V. Iribar, M. Manzano, A. Bayó and A. Galofré (1986), Evolution of sea } \\
\text { water intrusion in the Llobregat Delta, Barcelona, Spain, paper presented at the 9th Salt } \\
\text { Water Intrusion Meeting, Delft, The Netherlands } \\
\text { E. Falgas, J. Ledo, T. Teixido, A. Gabas, F. Ribera, C. Arango, P. Queralt, J.L. Plata, } \\
\text { F.M. Rubio, J.A. Pena, A. Marti, A. Marcuello (2004), Geophysical characterization of } \\
\text { a mediterranean coastal aquifer: The Baixa Tordera fluvio-deltaic aquifer unit } \\
\text { (Barcelona, NE Spain), paper presented at the 18th Salt Water Intrusion Meeting, } \\
\text { Cartagena, Spain }\end{array}$ \\
\hline 26 & $\begin{array}{l}\text { B. Aunay, C. Duvail, P. Le Strat, N. Dorfliger, P. Lachassagne and S. Pistre (2004), } \\
\text { Importance of a high resolution lithological and geometrical knowledge for } \\
\text { Mediterranean coastal sedimentary aquifers management. Application to the Roussillon } \\
\text { basin, South of France, paper presented at the 18th Salt Water Intrusion Meeting, } \\
\text { Cartagena, Spain }\end{array}$ \\
\hline 27 & $\begin{array}{l}\text { P. Cau, G. Lecca, L. Muscas, G. Barrocu and G. Uras (2002), Seawater intrusion in the } \\
\text { plain of Oristano (Sardinia, Italy), paper presented at the 17th Salt Water Intrusion } \\
\text { Meeting, Delft, The Netherlands }\end{array}$ \\
\hline 28 & $\begin{array}{l}\text { F. Ardau, R. Balia, G. Barbieri, G. Barrocu, E. Gavaudo and G. Ghiglieri (2002), } \\
\text { Recent development in hydrogeological and geophysical research in the Muravera } \\
\text { coastal plain (SE Sardinia, Italy), paper presented at the 17th Salt Water Intrusion } \\
\text { Meeting, Delft, The Netherlands }\end{array}$ \\
\hline 29 & $\begin{array}{l}\text { V. Ferrara and A. Pennisi (2004), Salt water intrusion and its influence on groundwater } \\
\text { use in the Siracusa area (south-eastern Sicily), paper presented at the 13th Salt Water } \\
\text { Intrusion Meeting, Cagliari, Italy }\end{array}$ \\
\hline 30 & $\begin{array}{l}\text { A. Bencini \& G. Pranzini (1992), The salinization of groundwaters in the Grosseto } \\
\text { Plain (Tuscany, Italy), paper presented at the 12th Salt Water Intrusion Meeting, } \\
\text { Barcelona, Spain }\end{array}$ \\
\hline 31 & $\begin{array}{l}\text { G. Pranzini (2002), Groundwater salinization in Versilia (Italy), paper presented at } \\
\text { the } 17^{\text {th }} \text { Salt Water Intrusion Meeting, Delft, The Netherlands }\end{array}$ \\
\hline 32 & $\begin{array}{l}\text { E. Van Houtte, L. Lebbe, L. Zeuwts and F. Vanlerberghe (2002), Concept for } \\
\text { development of sustainable drinking-water production in the Flemish coastal plain } \\
\text { based on integrated water management, paper presented at the } 17^{\text {th }} \text { Salt Water Intrusion } \\
\text { Meeting, Delft, The Netherlands } \\
\text { Lebbe, L.C. and K. Pede (1986), Salt-fresh water flow underneath old dunes and low } \\
\text { polders influenced by pumpage and drainage in the Western Belgian coastal plain, } \\
\text { paper presented at 9th Salt Water Intrusion Meeting, Delft, The Netherlands } \\
\text { Lebbe, L. and K. Walraevens (1988), Hydrogeological SWIM-excursion to the western } \\
\text { coastal plain of Belgium, paper presented at the 10th Salt Water Intrusion Meeting, } \\
\text { Gent, Belgium }\end{array}$ \\
\hline 33 & $\begin{array}{l}\text { Lotringen, I.G.J, van, and R. H. Boekelman (1986), Behaviour of circular fresh water } \\
\text { lenses, paper presented at the 9th Salt Water Intrusion Meeting, Delft, The Netherlands } \\
\text { Meerten, J.J. van, and R.H. Boekelman (1986), Well-infiltration in fresh-water pockets } \\
\text { in sandy ridges in Zeeland, paper presented at the 9th Salt Water Intrusion Meeting, } \\
\text { Delft, The Netherlands } \\
\text { Walraevens et al. (1988), Hydrogeological SWIM-excursion to the Black-Sluice Polder }\end{array}$ \\
\hline
\end{tabular}




\begin{tabular}{|c|c|}
\hline & $\begin{array}{l}\text { area in the Flemish Valley of Belgium, paper presented at the 10th Salt Water Intrusion } \\
\text { Meeting, Gent, Belgium }\end{array}$ \\
\hline 34 & $\begin{array}{l}\text { Delsman, J.R. et al., 2013. Palaeo-modeling of coastal salt water intrusion during the } \\
\text { Holocene: an application to the Netherlands. Hydrology and Earth System Sciences } \\
\text { Discussions, 10(11), pp.13707-13742. Available at: http://www.hydrol-earth-syst-sci- } \\
\text { discuss.net/10/13707/2013/hessd-10-13707-2013.html. } \\
\text { G.H.P. Oude Essink (2002), Salinization of the Wieringermeerpolder, The Netherlands, } \\
\text { paper presented at the 17th Salt Water Intrusion Meeting, Delft, The Netherlands } \\
\text { P.J. Stuyfzand (1992), Behaviour of major and trace consituents in fresh and salt } \\
\text { intrusion waters, in the western Netherlands, paper presented at the 12th Salt Water } \\
\text { Intrusion Meeting, Barcelona, Spain } \\
\text { Stuyfzand, P.J. (1988), Hydrochemical evidence of fresh- and salt-water intrusions in } \\
\text { the coastal dunes aquifer system of the western Netherlands, paper presented at the } \\
\text { 10th Salt Water Intrusion Meeting, Gent, Belgium } \\
\text { Pomper, A.B. (1972), Evidence of the influence of man on the natural processes related } \\
\text { with salinization of groundwater in the western part of West-Netherlands, paper } \\
\text { presented at the 3rd Salt Water Intrusion Meeting, Copenhagen, Denmark } \\
\text { Roebert, A.J. (1972), Salt water contamination of the wells along the Barnaart-Schuster } \\
\text { Canal in the Amsterdam Dune Water Catchment Area, paper presented at the 3rd Salt } \\
\text { Water Intrusion Meeting, Copenhagen, Denmark } \\
\text { Roebert, A.J. (1972), Salt water contamination of the wells along the Barnaart-Schuster } \\
\text { Canal in the Amsterdam Dune Water Catchment Area, paper presented at the 3rd Salt } \\
\text { Water Intrusion Meeting, Copenhagen, Denmark } \\
\text { Pomper, A.B. (1977), An estimation of chloride intrusion in the midwest } \\
\text { Netherlands during the Pleistocene epoch, paper presented at the 5th Salt Water } \\
\text { Intrusion Meeting, Medmenham, United Kingdom } \\
\text { De Vries, J.J. (1981), The distribution of fresh and salt groundwater in the Dutch } \\
\text { coastal area and the Quaternary-geological evolution, paper presented at the 7th Salt } \\
\text { Water Intrusion Meeting, Uppsala, Sweden }\end{array}$ \\
\hline 35 & $\begin{array}{l}\text { A. Rogge \& V. Josopait (1992), Salinization caused by groundwater abstraction from } \\
\text { an aquifer on the german North Sea coast, paper presented at the 12th Salt Water } \\
\text { Intrusion Meeting, Barcelona, Spain }\end{array}$ \\
\hline 36 & $\begin{array}{l}\text { M.D. Fidelibus, E. Gimenez, I. Morell \& L. Tulipano (1992), Salinization processes in } \\
\text { the Castellon plain aquifer (Spain), paper presented at the 12th Salt Water Intrusion } \\
\text { Meeting, Barcelona, Spain }\end{array}$ \\
\hline 37 & $\begin{array}{l}\text { A. Bayo, C. Loaso, J.M. Aragones \& E. Custodio (1992), Marine intrusion and } \\
\text { brackish water in coastal aquifers of Southern Catalonia and Castello (Spain): a brief } \\
\text { survey of actual problems and circumstances, paper presented at the 12th Salt Water } \\
\text { Intrusion Meeting, Barcelona, Spain }\end{array}$ \\
\hline 38 & $\begin{array}{l}\text { M. Fidelibus, F. Caporale and G. Spilotro (2004), Studies on different kinds of } \\
\text { salinisation in the ground waters of the Ionian coastal plain of the Basilicata region, } \\
\text { paper presented at the 18th Salt Water Intrusion Meeting, Cartagena, Spain }\end{array}$ \\
\hline 39 & (Planert \& Williams 1995) \\
\hline 40, 41 & $\begin{array}{l}\text { Olcott, P.G., 1995. Ground Water Atlas of the United States: Segment 12, Connecticut, } \\
\text { Maine, Massachusetts, New Hampshire, New York, Rhode Island, Vermont - ed., } \\
\text { Available at: http://pubs.er.usgs.gov/publication/ha730M. }\end{array}$ \\
\hline 42, 43, 44 & $\begin{array}{l}\text { Trapp Jr., H. \& Horn, M.A., 1997. Ground Water Atlas of the United States: Segment } \\
\text { 11, Delaware, Maryland, New Jersey, North Carolina, Pennsylvania, Virginia, West } \\
\text { Virginia - ed., }\end{array}$ \\
\hline 45 & $\begin{array}{l}\text { Ryder, P.D., 1996. Ground Water Atlas of the United States: Segment 4, Oklahoma, } \\
\text { Texas - ed., Available at: http://pubs.er.usgs.gov/publication/ha730E. }\end{array}$ \\
\hline 46, 47, 48 & $\begin{array}{l}\text { Renken, R.A., 1998. Ground Water Atlas of the United States: Segment 5, Arkansas, } \\
\text { Louisiana, Mississippi - ed., }\end{array}$ \\
\hline $49,50,51$ & Whitehead, R.L., 1994. Ground Water Atlas of the United States: Segment 7, Idaho, \\
\hline
\end{tabular}




\begin{tabular}{|l|l|}
\hline $\mathbf{5 2 , 5 3 , 5 4}$ & Oregon, Washington - ed., \\
\hline $\begin{array}{l}\text { Planert, M. \& Williams, J.S., 1995. Ground Water Atlas of the United States: Segment } \\
\text { 1, California, Nevada - ed., }\end{array}$ \\
\hline $\mathbf{5 8 , 5 9}$ & $\begin{array}{l}\text { Miller, J.A., 1990. Ground Water Atlas of the United States: Segment 6, Alabama, } \\
\text { Florida, Georgia, South Carolina - ed., Available at: } \\
\text { http://pubs.er.usgs.gov/publication/ha730G. }\end{array}$ \\
\hline $\mathbf{6 0}$ & $\begin{array}{l}\text { Tuttle, M.L.W., Charpentier, R. \& Brownfield, M.E., 1999. The Niger Delta Petroleum } \\
\text { System: Niger Delta Province, Nigeria, Cameroon, and Equatorial Guinea, Africa. } \\
\text { World Energy Project, (99-50-H), p.64. }\end{array}$ \\
\hline $\mathbf{6 1}$ & $\begin{array}{l}\text { M. Gennessaux, P.B. and E.W., 1998. Thickness of the Plio-Quaternary sediments } \\
\text { (IBCM-PQ). BOLLETTINO DI GEOFISICA TEORICA ED APPLICATA, 39(4), } \\
\text { pp.243-284. }\end{array}$ \\
\hline $\mathbf{6 2}$ & $\begin{array}{l}\text { Al Farrah, N., Van Camp, M. \& Walraevens, K., 2013. Deducing transmissivity from } \\
\text { specific capacity in the heterogeneous upper aquifer system of Jifarah Plain, NW- } \\
\text { Libya. Journal of African Earth Sciences, 85, pp.12-21. Available at: } \\
\text { http://dx.doi.org/10.1016/j.jafrearsci.2013.04.004. }\end{array}$ \\
\hline $\mathbf{6 3}$ & $\begin{array}{l}\text { Van Camp, M. et al., 2014. Investigating seawater intrusion due to groundwater } \\
\text { pumping with schematic model simulations: The example of the Dar es Salaam coastal } \\
\text { aquifer in Tanzania. Journal of African Earth Sciences, 96, pp.71-78. Available at: } \\
\text { http://dx.doi.org/10.1016/j.jafrearsci.2014.02.012. }\end{array}$ \\
\hline $\mathbf{6 4}$ & $\begin{array}{l}\text { Kumar, B. et al., 2011. Groundwater management in a coastal aquifer in Krishna River } \\
\text { Delta, South India using isotopic approach., 100(7). }\end{array}$ \\
\hline
\end{tabular}


Table S3. Aquifer thickness information provided by the literature sources compared with the ATE values for each coastal area (column "id", corresponds to ID values in Figure S6). For each are the location is also given. The values from literature are shown in columns below the "Measured values" header while our ATE values are below the "ATE values" header. The "calc_avg" column represents the calculated average value in cases where only min., max. or both were given by the literature. The "calc_avg" is calculated as either the arithmetic average between the min. and max. values or as min./max. value $+/$ - half of min./max.

\begin{tabular}{|c|c|c|c|c|c|c|c|c|}
\hline & \multicolumn{3}{|c|}{ Measured values (m) } & \multirow[b]{2}{*}{ calc_avg } & \multicolumn{3}{|c|}{ ATE values (m) } & \multirow[b]{2}{*}{ location } \\
\hline id & thick_max & thick_min & thick_avg & & est_avg & est_min & est_max & \\
\hline 1 & 600 & & & 300 & 501.1 & 323.1 & 768.0 & Godavari delta (IND) \\
\hline 2 & & & 130 & 130 & 174.8 & 76.2 & 386.9 & Digha (IND) \\
\hline 3 & & & 80 & 80 & 76.2 & 35.7 & 173.9 & Songkhla (THA) \\
\hline 4 & & & 100 & 100 & 84.6 & 36.0 & 124.1 & Wadi Ham (UAE) \\
\hline 5 & & & 50 & 50 & 72.9 & 41.2 & 120.0 & Carnavon (AUS) \\
\hline 6 & 600 & & & 300 & 272.2 & 51.0 & 897.8 & Mekong (VNM) \\
\hline 7 & 100 & 20 & 70 & 70 & 116.9 & 30.6 & 244.3 & Rabat (MAR) \\
\hline 8 & 500 & 300 & & 400 & 281.0 & 41.7 & 648.4 & South Jangtze coast, NE (CHN) \\
\hline 9 & 600 & & & 300 & 161.9 & 64.9 & 308.4 & Goksu plain (TUR) \\
\hline 10 & 20 & & & 10 & 34.9 & 22.3 & 51.2 & Mar de Ajo (ARG) \\
\hline 11 & & & 50 & 50 & 277.4 & 49.0 & 750.8 & Falster island (DKN) \\
\hline 12 & & & 50 & 50 & 215.6 & 2.1 & 5143.4 & Riga gulf (EST) \\
\hline 13 & & & 200 & 200 & 238.5 & 53.5 & 615.2 & South Jangtze coast, SW (CHN) \\
\hline 14 & 900 & & & 450 & 484.8 & 33.5 & 1394.4 & Nile delta (EGY) \\
\hline 15 & 45 & & 25 & 25 & 210.1 & 83.8 & 333.9 & Thamirabarani delta (IND) \\
\hline 16 & 100 & & & 50 & 190.9 & 93.5 & 310.7 & Kuala Lumpur (MYS) \\
\hline 17 & 150 & & & 75 & 79.9 & 2.2 & 371.3 & Saloum delta (SEN) \\
\hline 18 & & 1000 & & & 261.0 & 40.7 & 984.0 & Kilwa group (TZA) \\
\hline 19 & 250 & & 200 & 200 & 278.9 & 44.8 & 649.5 & Coastal aquifer (ISR) \\
\hline 20 & 300 & & 250 & 250 & 268.8 & 41.5 & 483.1 & Bekasi (IDN) \\
\hline 21 & 420 & & & 210 & 110.9 & 9.4 & 331.7 & Perth Basin (AUS) \\
\hline 22 & 1000 & 50 & 600 & 600 & 161.8 & 5.0 & 1091.9 & Great artesian basin (AUS) \\
\hline 23 & 120 & & & 60 & 106.8 & 1.1 & 496.4 & Canning Basin (AUS) \\
\hline 24 & 1000 & 150 & & 575 & 166.0 & 53.4 & 399.6 & Doñana National Park (ESP) \\
\hline 25 & 180 & 50 & & 115 & 109.7 & 67.3 & 186.5 & Barcelona (ESP) \\
\hline 26 & 200 & 80 & & 140 & 119.0 & 39.8 & 163.9 & Perpignan (FRA) \\
\hline 27 & 218 & 18 & 120 & 120 & 104.2 & 0.4 & 247.3 & Oristano (ITA) \\
\hline 28 & 300 & & & 150 & 84.1 & 40.7 & 128.5 & Muravera (ITA) \\
\hline 29 & 100 & & & 50 & 177.6 & 89.2 & 236.5 & Siracusa (ITA) \\
\hline 30 & 200 & & & 100 & 150.8 & 81.1 & 201.2 & Grosseto (ITA) \\
\hline 31 & & 100 & & 200 & 153.4 & 2.1 & 317.0 & Versilia (ITA) \\
\hline 32 & 150 & 25 & 100 & 100 & 116.8 & 54.5 & 312.9 & Coastal aquifer (BEL) \\
\hline 33 & 315 & 30 & 90 & 90 & 185.2 & 62.1 & 436.4 & Northern dutch coast (NLD) \\
\hline 34 & 600 & 100 & 200 & 200 & 441.1 & 165.4 & 875.9 & Zeeland (NLD) \\
\hline 35 & 175 & 125 & & 150 & 66.3 & 16.6 & 261.9 & Wilhelmshaven (GER) \\
\hline 36 & 200 & 80 & & 140 & 125.7 & 58.4 & 180.0 & Castellon de la Plana (ESP) \\
\hline 37 & & & 200 & 200 & 187.8 & 91.5 & 429.0 & Ebro delta (ESP) \\
\hline 38 & & & 100 & 100 & 131.6 & 78.8 & 211.3 & Scanzano (ITA) \\
\hline 39 & 300 & & & 150 & 123.7 & 13.5 & 331.6 & Eureka aquifer, CA (USA) \\
\hline 40 & 300 & 30 & & 165 & 165.8 & 28.3 & 520.4 & Cape Cod (USA) \\
\hline 41 & 600 & 170 & & 385 & 260.8 & 1.4 & 1245.4 & Long Island (USA) \\
\hline 42 & 1200 & & & 600 & 285.0 & 33.7 & 815.5 & North Atlantic coastal plain, NJ (USA) \\
\hline 43 & 2400 & & & 1200 & 295.9 & 21.8 & 2028.6 & North Atlantic coastal plain, MA (USA) \\
\hline 44 & 3100 & & & 1550 & 444.8 & 6.4 & 4983.9 & North Atlantic coastal plain, NC (USA) \\
\hline 45 & 2000 & 300 & & 1150 & 266.5 & 24.5 & 2652.5 & Coastal lowlands aq. system, TX (USA) \\
\hline 46 & 2400 & 1200 & & 1800 & 83.9 & 72.9 & 94.8 & Coastal lowlands aq. system SE, LA (USA) \\
\hline 47 & 3600 & 1200 & & 2400 & 367.7 & 120.6 & 1085.5 & Coastal lowlands aq. system NW, LA (USA) \\
\hline 48 & 1000 & & & 500 & 204.7 & 22.2 & 815.7 & Mississippi emayment aq. (USA) \\
\hline 49 & 1000 & & & 500 & 130.8 & 2.2 & 496.7 & Puget-Williamette trough regional aq. system (USA) \\
\hline 50 & 35 & 15 & & 25 & 97.4 & 16.2 & 388.0 & Washington coast $\mathrm{N}$ (USA) \\
\hline 51 & 200 & 35 & & 117.5 & 138.7 & 14.1 & 318.1 & Washington coast S (USA) \\
\hline 52 & 300 & & & 150 & 75.7 & 3.7 & 182.3 & Santa Clara valley (USA) \\
\hline 53 & 300 & & & 150 & 162.9 & 92.7 & 204.2 & Salinas Valley (USA) \\
\hline 54 & 1200 & 30 & & 615 & 286.6 & 130.3 & 492.4 & Los Angeles - Orange county (USA) \\
\hline 55 & 1000 & 200 & & 600 & 170.2 & 7.0 & 1762.3 & $\mathrm{FL}-\mathrm{W}$ and $\mathrm{AL}$ coast (USA) \\
\hline 56 & 1050 & 850 & & 950 & 95.5 & 1.9 & 1172.4 & $\mathrm{FL}-\mathrm{S}(\mathrm{USA})$ \\
\hline 57 & 200 & 60 & & 130 & 210.7 & 30.0 & 1293.4 & SC-S (USA) \\
\hline 58 & 850 & 200 & & 525 & 167.0 & 52.0 & 723.7 & Georgia coast (USA) \\
\hline 59 & 850 & 700 & & 775 & 189.5 & 6.1 & 2079.0 & $\mathrm{FL}-\mathrm{N}(\mathrm{USA})$ \\
\hline 60 & 2000 & & & 1000 & 171.7 & 1.3 & 805.5 & Niger delta (NGA) \\
\hline 61 & 1200 & & & 600 & 415.4 & 46.3 & 929.4 & Po delta (ITA) \\
\hline 62 & 180 & 30 & & 105 & 247.3 & 4.7 & 490.5 & Jifarah Plain (LBY) \\
\hline 63 & & & 150 & 150 & 295.2 & 88.0 & 1049.5 & Dar es Salaam (TZA) \\
\hline 64 & 450 & 40 & & 245 & 286.6 & 65.2 & 608.0 & Kirishna river delta (IND) \\
\hline
\end{tabular}


Table S4 Parameter values for the three cross-sections, the values are given for models with minimum and maximum estimated sediment thickness at the coastline. The total length of simulation for the test case in Virginia, USA is larger than for the other two test cases due to the complexity and size of the aquifer system. This was done to ensure that the steady-state (or near steady-state) is reached, for the changes of fresh groundwater cells in time see Figure S10 in the Supplementary information.

\begin{tabular}{|c|c|c|c|c|c|c|}
\hline & \multicolumn{2}{|c|}{ Italy } & \multicolumn{2}{|c|}{ Israel } & \multicolumn{2}{|c|}{ Virginia, USA } \\
\hline Sediment thickness at coastline & $50 \mathrm{~m}$ & $500 \mathrm{~m}$ & $100 \mathrm{~m}$ & $1400 \mathrm{~m}$ & $200 \mathrm{~m}$ & $1500 \mathrm{~m}$ \\
\hline Number of columns & 1,060 & 1,588 & 385 & 494 & 547 & 578 \\
\hline Number of layers & 53 & 411 & 43 & 110 & 44 & 106 \\
\hline Layer thickness (m) & \multicolumn{2}{|c|}{3} & \multicolumn{2}{|c|}{10} & \multicolumn{2}{|c|}{10} \\
\hline Column width (m) & \multicolumn{2}{|c|}{25} & \multicolumn{2}{|c|}{100} & \multicolumn{2}{|c|}{500} \\
\hline Top elevation (m asl.) & \multicolumn{2}{|c|}{26} & \multicolumn{2}{|c|}{95} & \multicolumn{2}{|c|}{59} \\
\hline Bottom elevation ( $\mathrm{m}$ asl.) & -62 & $-1,002$ & -335 & $-1,005$ & -381 & $-1,001$ \\
\hline Length of simulation (years) & \multicolumn{4}{|c|}{10,000} & \multicolumn{2}{|c|}{100,000} \\
\hline Number of time steps & \multicolumn{4}{|c|}{2,500} & \multicolumn{2}{|c|}{10,000} \\
\hline Total active cells & 13,224 & 534,879 & 3,021 & 30,332 & 9,319 & 43,630 \\
\hline Horizontal hydraulic conductivity aquifer $(\mathrm{m} / \mathrm{d})$ & \multicolumn{6}{|c|}{10} \\
\hline Vertical hydraulic conductivity aquifer (m/d) & \multicolumn{6}{|c|}{1} \\
\hline Horizontal hydraulic conductivity aquitard (m/d) & \multicolumn{2}{|c|}{$1.00 \mathrm{E}-04$} & \multicolumn{2}{|c|}{$1.00 \mathrm{E}-04$} & \multicolumn{2}{|c|}{$1.00 \mathrm{E}-04$} \\
\hline Vertical hydraulic conductivity aquitard (m/d) & \multicolumn{2}{|c|}{$1.00 \mathrm{E}-07$} & \multicolumn{2}{|c|}{$1.00 \mathrm{E}-07$} & \multicolumn{2}{|c|}{$1.00 \mathrm{E}-07$} \\
\hline Layer type & \multicolumn{6}{|c|}{ confined } \\
\hline Total amount of GHB cells & 887 & 1415 & 200 & 321 & 274 & 431 \\
\hline Recharge rate $(\mathrm{m} / \mathrm{d})$ & \multicolumn{2}{|c|}{0.001} & \multicolumn{4}{|c|}{0.0005} \\
\hline Head change criterion for convergence $(\mathrm{m})$ & \multicolumn{6}{|c|}{$1.00 \mathrm{E}-04$} \\
\hline Residual criterion for convergence $\left(\mathrm{m}^{3} / \mathrm{d}\right)$ & \multicolumn{6}{|c|}{10} \\
\hline Porosity & \multicolumn{6}{|c|}{0.35} \\
\hline Solver type & \multicolumn{6}{|c|}{ Finite Difference } \\
\hline Longitudinal dispersivity & \multicolumn{6}{|c|}{1} \\
\hline Ratio horizontal transverse disp./ long. disp. & \multicolumn{6}{|c|}{0.1} \\
\hline Diffusion coefficient $\left(\mathrm{m}^{2} / \mathrm{d}\right)$ & & & & E-05 & & \\
\hline
\end{tabular}




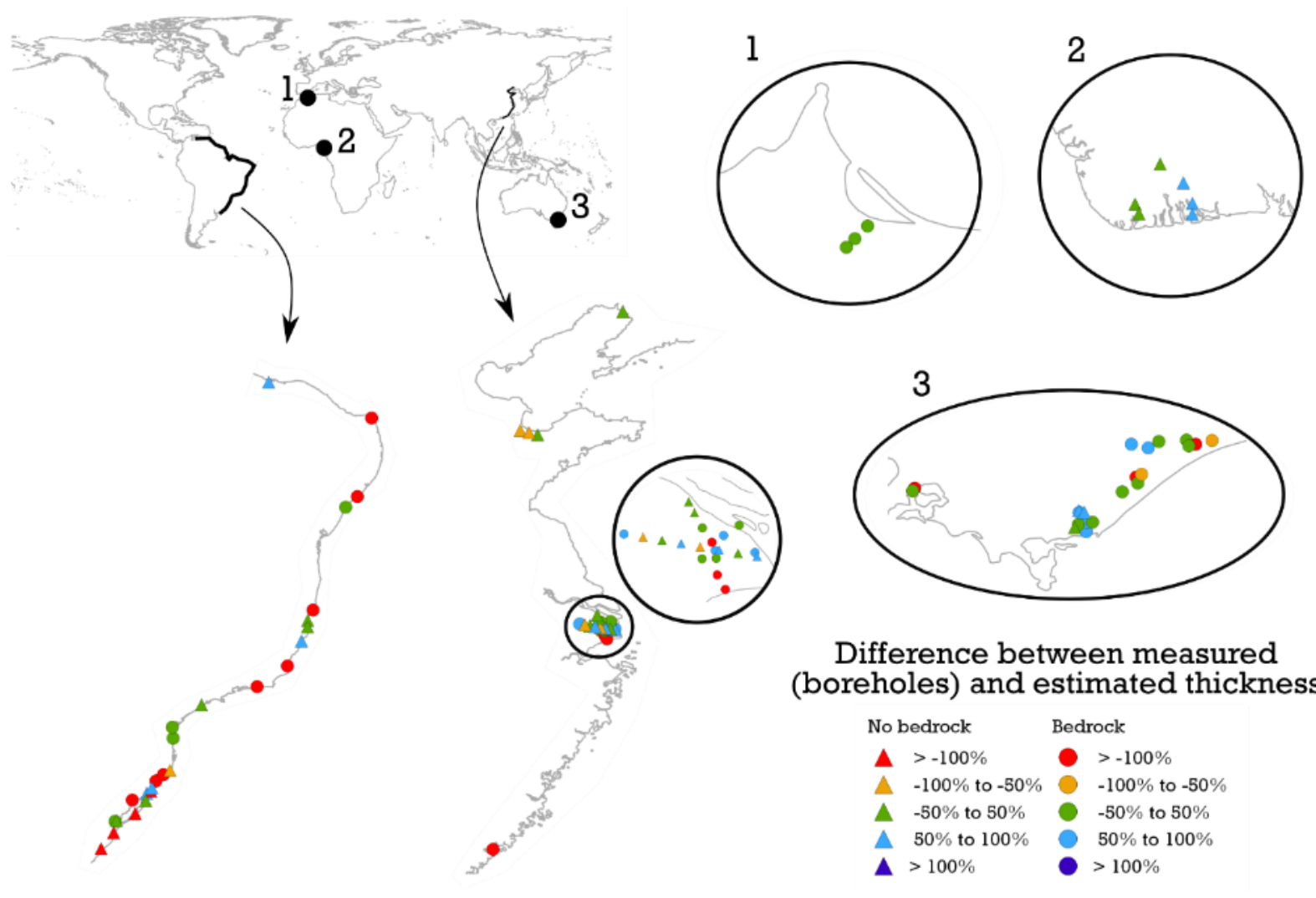

Figure S1. Schematization of borehole validation using the difference between the measured sediment thickness and an average estimated thickness in a radius of $2.5 \mathrm{~km}$ around the borehole location. The boreholes are divided into two groups depending on any bedrock formation indicated in the borehole report. 


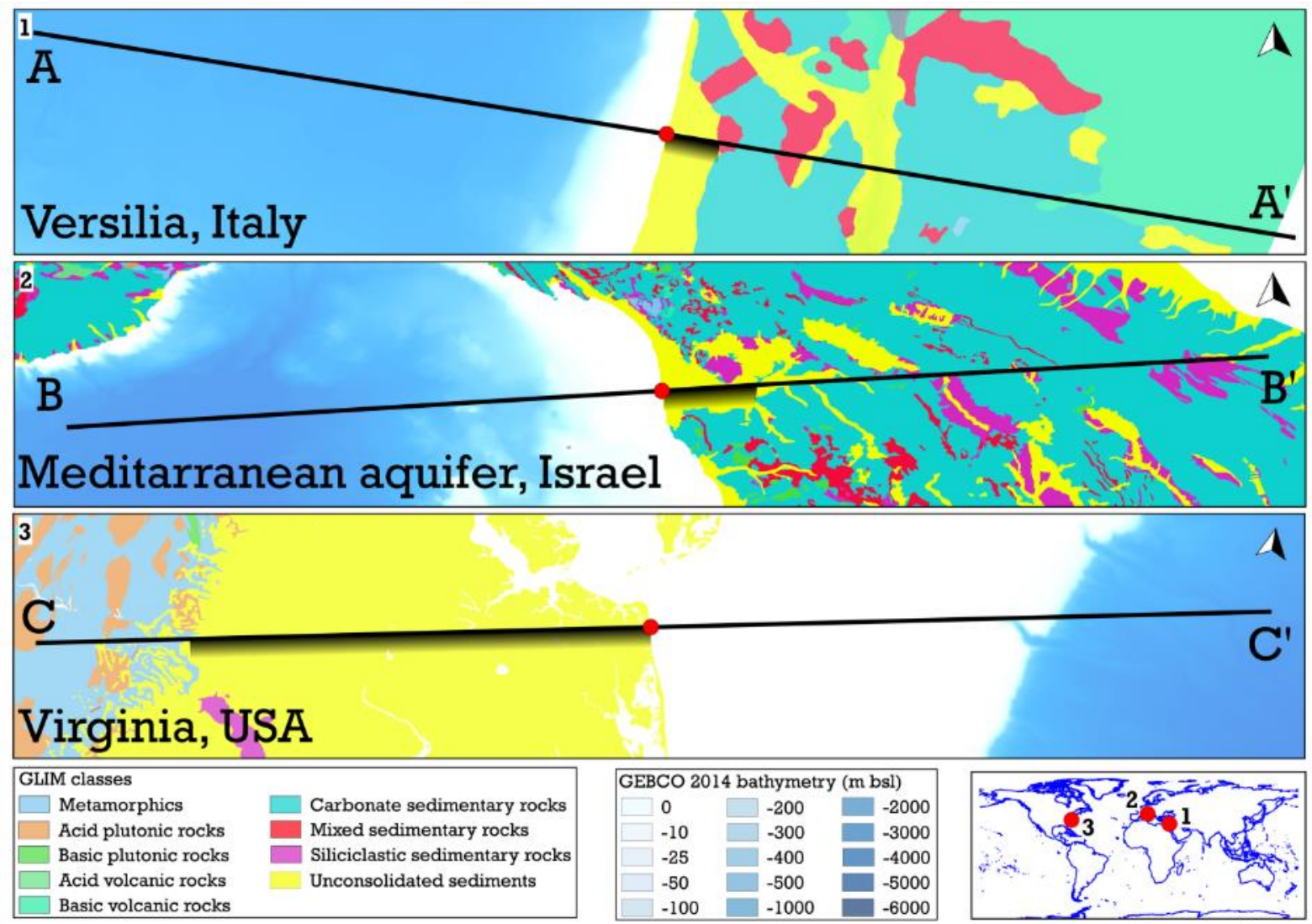

Figure S2. Location of the cross-sections used as examples to illustrate the ATE method. The black shadow represents the extent of the coastal plain in each cross-section while the whole black line indicates the span of the cross-section (in total $400 \mathrm{~km}$ ). 

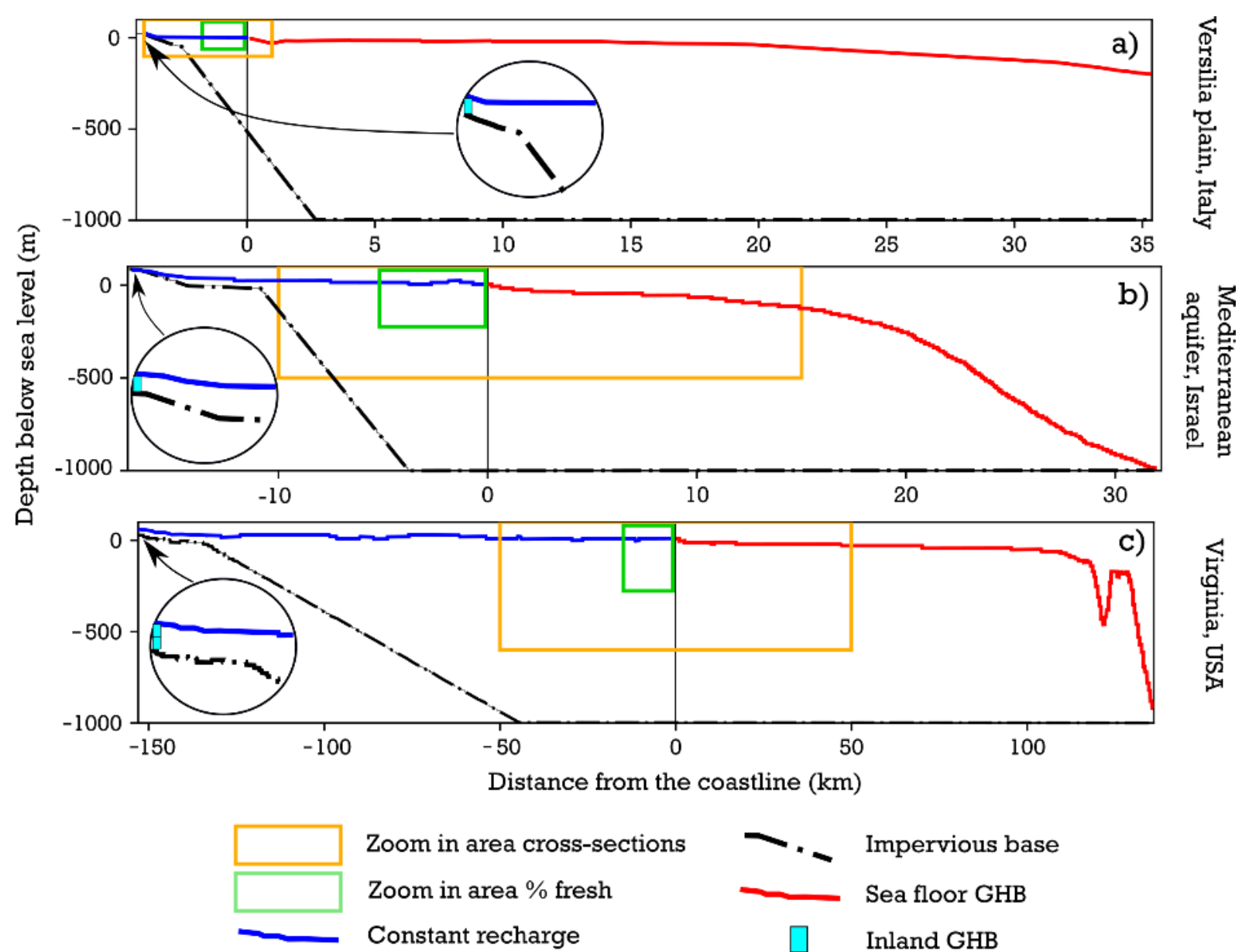

Figure S3. Model concept schematization for all three test cases. a) Versilia plain, Italy, b) Mediterranean aquifer, Israel and c) Virginia, USA. The zoom in area cross-section corresponds to the areas shown in Figures S8-S10 and Figure 4 in the main article. 
Complex geology

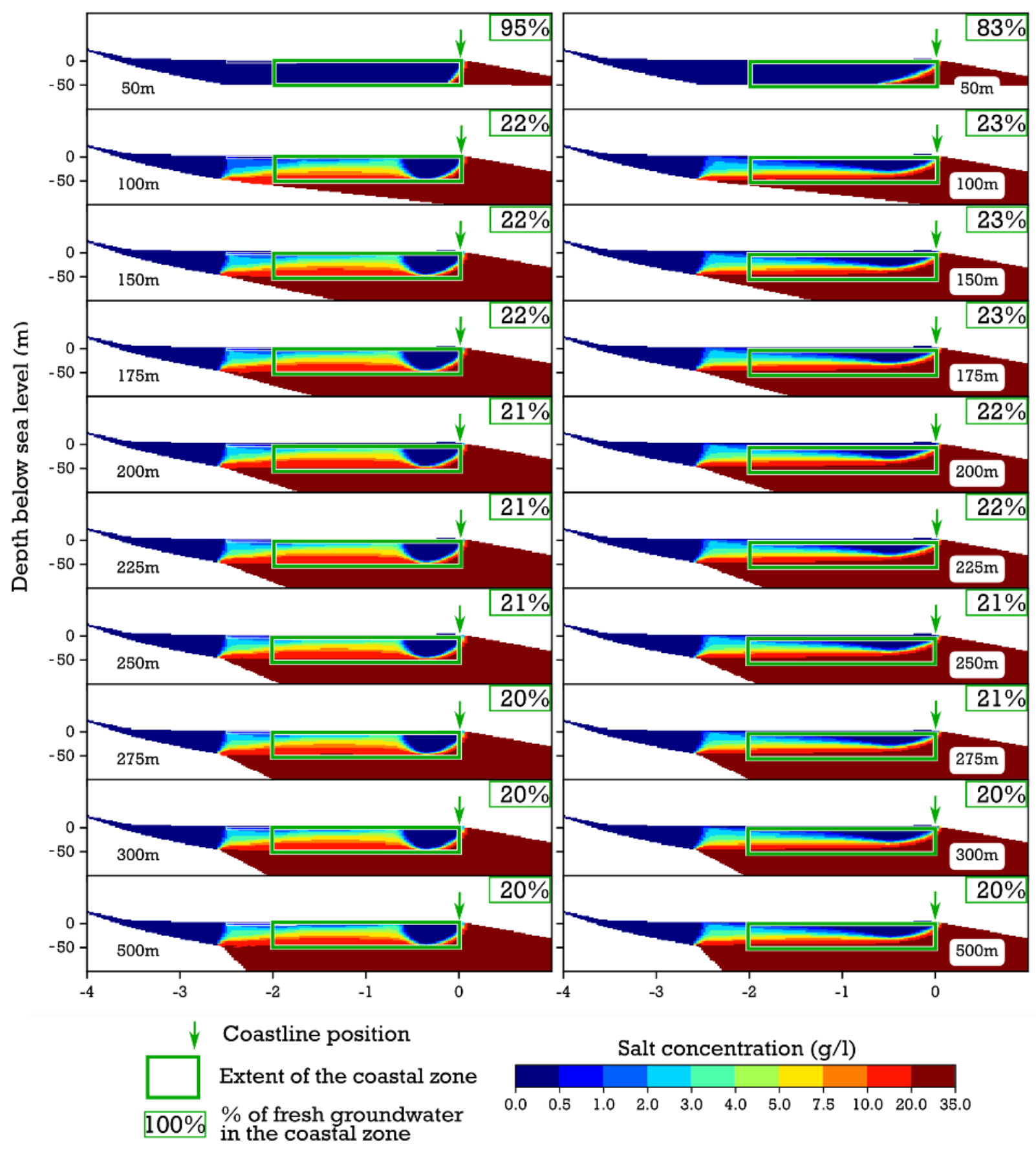

Simple geology 


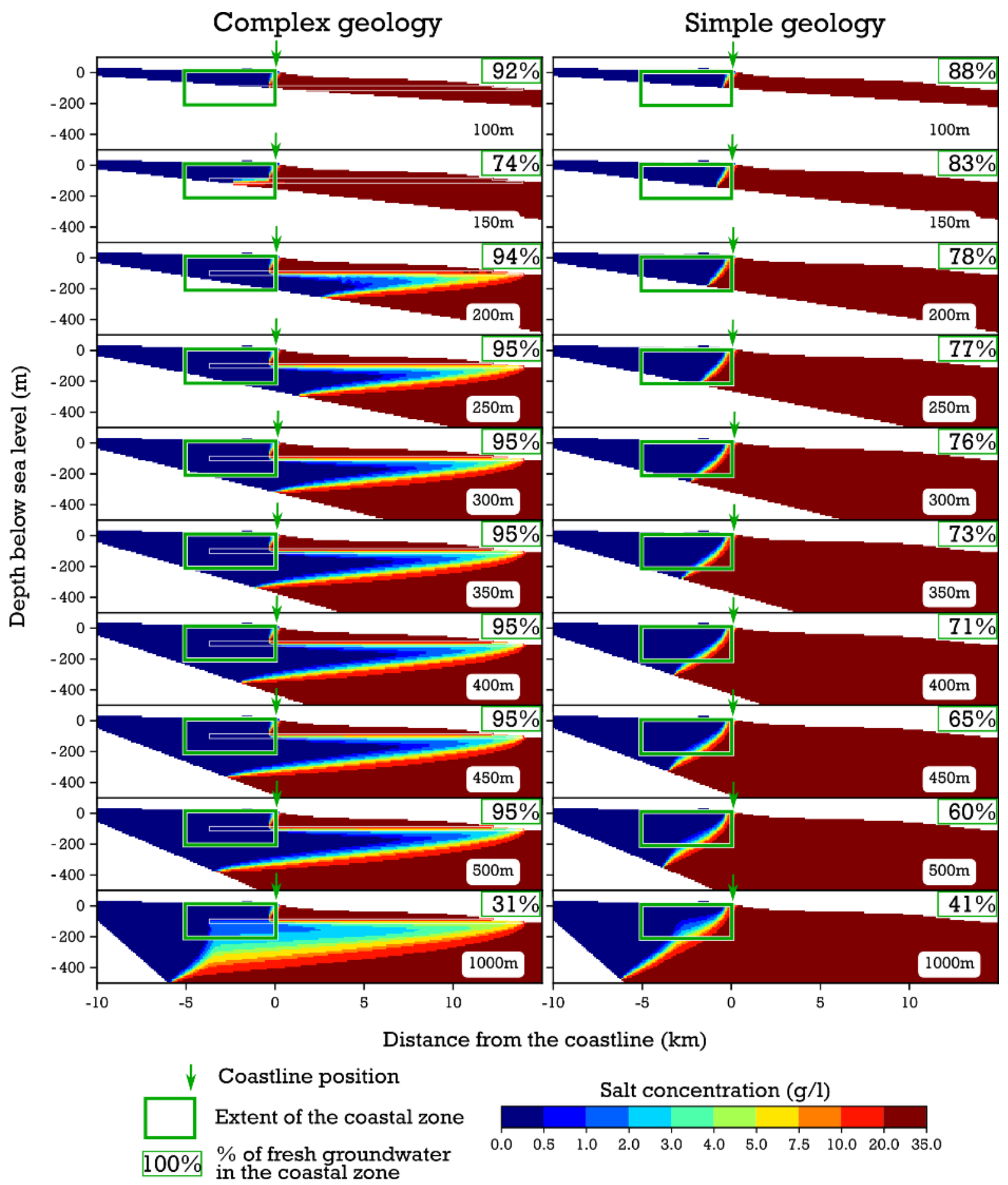

Figure S5. Simulation results for the cross-section located in the Mediterranean coastal plain aquifer, Israel. Salt concentration profiles are given for various sediment thicknesses at the coastline and two different geological scenarios (homogeneous and heterogeneous based on information provided by literature). 


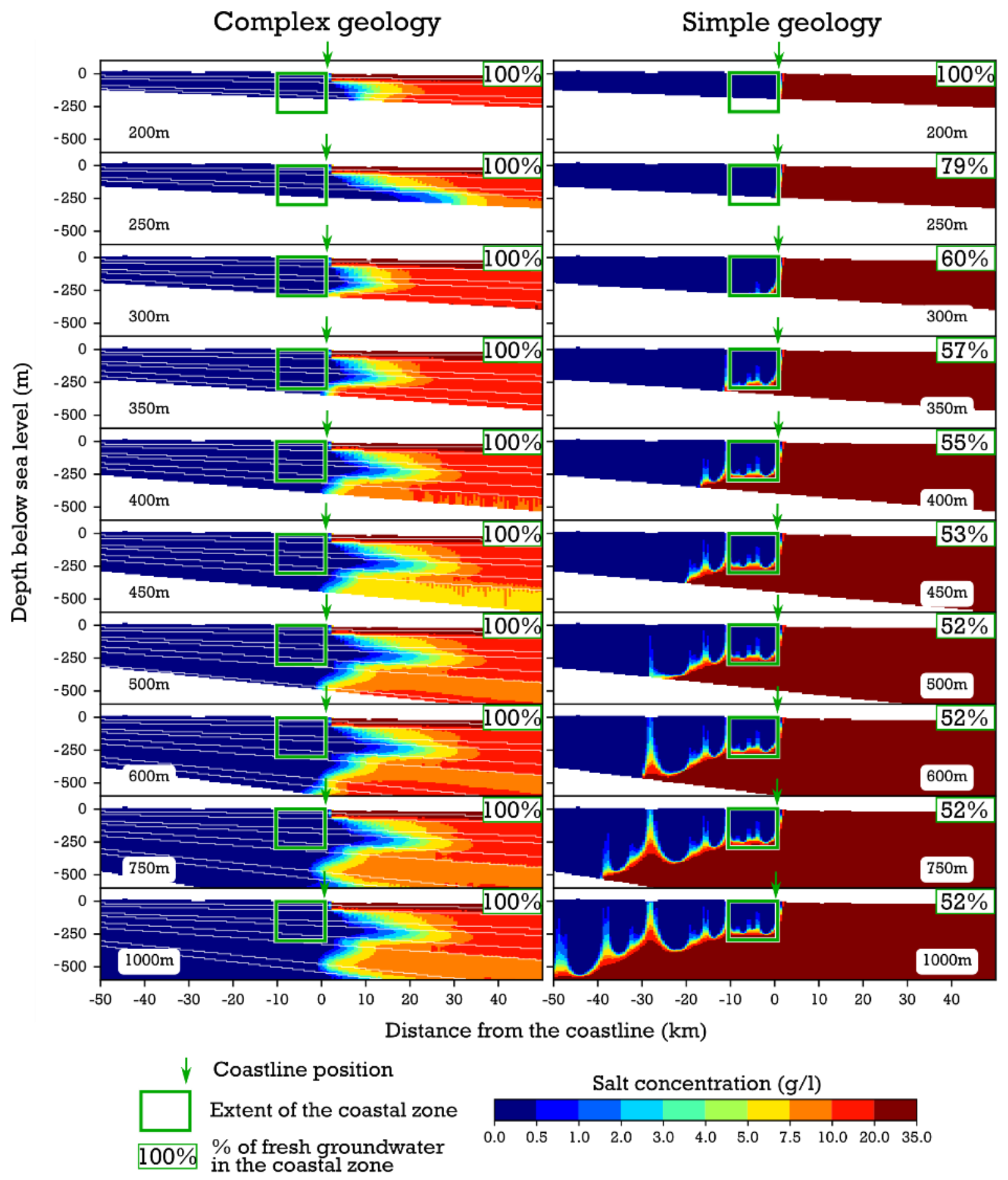

Figure S6. Simulation results for the cross-section located in North Atlantic Coastal Plain, Virginia, USA. Salt concentration profiles are given for various sediment thicknesses at the coastline and two different geological scenarios (homogeneous and heterogeneous based on information provided by literature). 